\title{
A Brief Review of Carbon Dioxide Hydrogenation to Methanol over Copper and Iron Based Catalysts
}

\author{
Obid Tursunov", Leonid Kustov and Aleksandr Kustov \\ The Laboratory of Nanochemistry and Ecology, Institute of Ecotechnology and Engineering, National University of Science \\ and Technology (MISiS), Moscow - Russia \\ e-maill: obidtursunov@gmail.com \\ *Corresponding author
}

\begin{abstract}
Climate change and global warming have become a challenging issue affecting not only humanity but also flora and fauna due to an intense increase of $\mathrm{CO}_{2}$ emission in the atmosphere which has gradually led to amplification in the average global temperature. Hence, a number of mechanisms have been promoted to diminish the atmospheric commutation of carbon dioxide. One of the well-known techniques is Carbon Capture and Storage (CCS) which mechanism is based on capture and storage vast quantities of $\mathrm{CO}_{2}$, as well as Carbon Capture and Utilization (CCU) which mechanism is based on $\mathrm{CO}_{2}$ conversion to liquid fuels (e.g. methanol, hydrocarbons, carbonate, propylene, dimethyl ether, ethylene, etc.). Particularly, methanol $\left(\mathrm{CH}_{3} \mathrm{OH}\right)$ is a key feedstock for industrial chemicals, which further can be converted into high molecular alternative liquid fuels. In this regard, hydrogenation of $\mathrm{CO}_{2}$ is one of the promising, effectual and economic techniques for utilization of $\mathrm{CO}_{2}$ emission. Nevertheless, the reduction/activation of $\mathrm{CO}_{2}$ into useful liquid products is a scientifically challenging issue due to the complexities associated with its high stability. Thus, various catalysts have been applied to reduce the activation energy of the hydrogenation process and transform $\mathrm{CO}_{2}$ into value-added products. Thereby, this review article highlights the progress and the recent advances of research investigation in $\mathrm{Cu}$ and $\mathrm{Fe}$-based catalytic conversion of $\mathrm{CO}_{2}$, reaction mechanisms, catalytic reactivity, and influence of operating parameters on product efficiency.
\end{abstract}

\section{INTRODUCTION}

Worldwide energy consumption is rapidly amplifying due to the growth of economy and population. The dominant percentage of the energy is extracted via the incineration of non-renewable fossil fuels and resources, which definitely causes the production of greenhouse gases and extensive accumulation of carbon dioxide $\left(\mathrm{CO}_{2}\right)$ in the atmosphere which is one of the crucial reasons for global warming and climate change. First of all, the scholars from similar fields recognize the immensely high contribution of $\mathrm{CO}_{2}$ as a greenhouse gas to global warming and this was endorsed by the leaders of not only developed but also developing countries during the previous world summit for climate change.
Figure 1 presents the evolution of annual emissions of $\mathrm{CO}_{2}$ for the period between 1990 and 2014, as well as estimated carbon dioxide emissions to 2019. From the figure it can be observed that $\mathrm{CO}_{2}$ emissions are slowly expanding or quite stable until approximately 2002 . Since 2003, there has been a sharp increasing trend which in particular overlaps with the increasing global temperatures and attenuating between the temperatures and the sunspot numbers. Friedlingstein et al. [1] report that the global greenhouse gas would continuously grow in 2014 to a level of approximately $65 \%$ above emissions in 1990 . The rapid growth the level of carbon dioxide in ambient air might cause to uninhabitable and irreversible planet for our future generations. At the same time we need to undoubtedly 


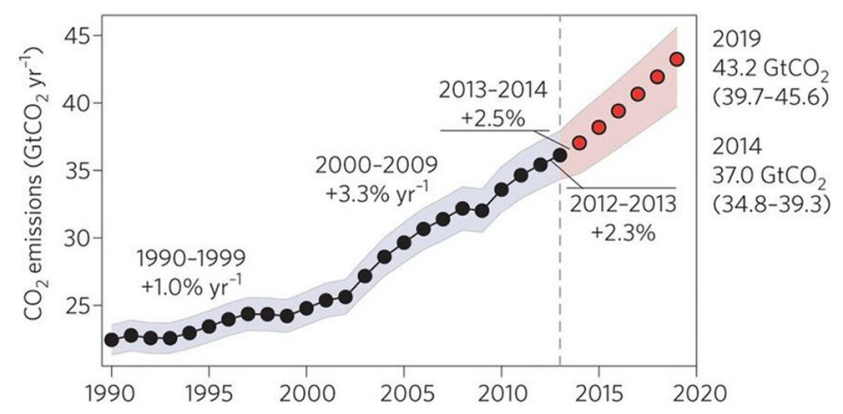

Figure 1

Global carbon dioxide emissions from fossil fuel combustion and cement production by 2014 (black dotes) and estimates to 2019 (red dots) [1].

increase our energy supply while reducing $\mathrm{CO}_{2}$ emissions is one of the essential challenges encountering our global society today. The worldwide $\mathrm{CO}_{2}$ emission should have to be diminished by $50-80 \%$ by 2050 in order to control the global mean temperature increase by $2-2.4^{\circ} \mathrm{C}$ [2]. Hu et al. [3] state the global $\mathrm{CO}_{2}$ emission from the use of fossil fuels and cement production was 36 billion tones in 2013 . Consequently, the robust and clean technologies for $\mathrm{CO}_{2}$ capture, storage and utilization are required at a large scale $[4,5]$. Among the technologies, effective strategies in chemical (e.g. hydrogenation) conversion could play a considerable role in reduction $\mathrm{CO}_{2}$ emission [6-8].

Catalytic conversion of $\mathrm{CO}_{2}$ to methanol $\left(\mathrm{CH}_{3} \mathrm{OH}\right)$ is considered as a promising way that might offer a comprehensive solution to the issues of greenhouse gas control and depletion of fossil fuels respectively. Methanol is a significant starting product for a number of valuable chemicals and can be applied as a clean fuel and fuel additive. Additionally, it can also be converted into aromatics, ethylene, and propylene as well as to other value-added petrochemicals that are nowadays mainly derived extracted from crude oil [9]. Moreover, methanol was mainly applied as a starting feedstock in the chemical industries and it could also be an efficient sustainable and alternative synthetic fuel if anthropogenic $\mathrm{CO}_{2}$ and regenerative hydrogen are used as reagent for its synthesis. One of the most effective ways of accomplishing this goal is to explore high selective and active catalysts for methanol synthesis due to its thermodynamic stability of $\mathrm{CO}_{2}$.

Thus, this review paper discusses the process, namely methanol synthesis via hydrogenation of $\mathrm{CO}_{2}$. The review starts with accurate highlights regarding to $\mathrm{CO}_{2}$ hydrogenation to methanol, reaction mechanism, and continues with the effect of selected catalysts and the effect of operating parameters on $\mathrm{H}_{2} / \mathrm{CO}_{2}$ to methanol, as well as recent technological and industrial advances in this field.

\section{$1 \mathrm{CO}_{2}$ HYDROGENATION TO METHANOL}

Currently, comprehensive efforts and attentions are being paid on conversion of $\mathrm{CO}_{2}$ to methanol. Olah et al. [10] reported that $\mathrm{CO}_{2}$ hydrogenation to methanol, a new concept of "methanol economy" which relies on combination of Carbon Capture and Storage (CCS) with chemical recycling. Whereas renewable feedstock such as $\mathrm{CO}_{2}$ and water are abundantly available, the energy required for the synthetic carbon cycle can come from any source of alternative energy like wind, solar, nuclear, and geothermal energy. This alternative cycle offers a robust mechanism ensuring sustainable future for human beings when fossil fuels become deficient.

The major reactions for hydrogenation of $\mathrm{CO}_{2}$ to methanol are methanol synthesis (Eq. (1)) and water-gas-shift reaction (Eq. (2)). There is a possibility that $\mathrm{CO}$ formed from reaction (Eq. (2)) that incurs further hydrogenation to generate methanol (Eq. (3)) [11]. The methanol formation is an exothermal reaction with reduction of reaction molecule. Hence, the rise of pressure and the decrease of temperature should favor for the reaction from thermodynamical analysis. Nevertheless, taking into account the chemically inert nature of $\mathrm{CO}_{2}$ and the reaction rate, the amplification of reaction temperature (e.g. $>240^{\circ} \mathrm{C}$ ) promotes activation of $\mathrm{CO}_{2}$ and then formation of methanol. The reverse water-gas-shift reaction leads to a reduction of methanol formation and causes extra consumption of hydrogen. Inui and Takeguchi [12] report that the large amount of water from by-product, from both the reverse water-gas-shift side reaction and synthesis of methanol, also had an inhibitory effect on the active metal during the reaction, thus leading to the catalyst deactivation. Consequently, synthesis of methanol from $\mathrm{CO}_{2}$ hydrogenation needs more selective catalysts in order to avoid the formation of unnecessary and undesired by-products.

$$
\begin{aligned}
& \mathrm{CO}_{2}+3 \mathrm{H}_{2}=\mathrm{CH}_{3} \mathrm{OH}+\mathrm{H}_{2} \mathrm{O}, \\
& \quad \Delta H_{298} \mathrm{~K}, 5 \mathrm{MPa}=-40.9 \mathrm{~kJ} / \mathrm{mol} \quad[\text { methnol formation }]
\end{aligned}
$$

$$
\begin{aligned}
& \mathrm{CO}_{2}+\mathrm{H}_{2}=\mathrm{CO}+\mathrm{H}_{2} \mathrm{O}, \\
& \Delta H_{298 \mathrm{~K}, 5 \mathrm{MPa}}=-49.8 \mathrm{~kJ} / \mathrm{mol} \text { [reverse water-gas-shift }
\end{aligned}
$$

$$
\mathrm{CO}+2 \mathrm{H}_{2}=\mathrm{CH}_{3} \mathrm{OH}, \quad \Delta H_{298 \mathrm{~K}, 5 \mathrm{MPa}}=-90.7 \mathrm{~kJ} / \mathrm{mol}
$$

$$
\text { [methanol formation] }
$$

Li et al. [13] proclaim that catalysts applied in hydrogenation of $\mathrm{CO}_{2}$ are those used for synthesis of methanol from CO hydrogenation. Several research investigations [14-17] have emphasized on the effects of catalyst type (e.g. surface area, morphology, supports and 
promoters), operating conditions, reactor type, etc. Indeed, catalysts with high efficiency are key factor for synthesis of methanol through $\mathrm{CO}_{2}$ hydrogenation. So far, the sustainable development of the catalyst is still not fully satisfactory in order to be applied for industrial applications due to the insufficient knowledge in catalytic design, properties and rational understanding of the $\mathrm{CO}_{2}$ hydrogenation mechanism. However, more large-scale research on catalytic activities, efficiency and practical upgrade of $\mathrm{Cu}$ - and $\mathrm{Fe}-$ based catalysts could break the above-mentioned gap in industrial application of $\mathrm{CO}_{2}$ hydrogenation to methanol.

\subsection{Reaction mechanism}

Due to significant complexity of methanol synthesis from hydrogenation of $\mathrm{CO}_{2}$, atomic level perception regarding to the reaction mechanism has been a lingering challenge. Liu et al. [18] state that so far, the key issues in the field, such as where and how $\mathrm{CO}_{2}$ is activated over the surface of the selected catalysts, remain infirm. The reaction mechanism has been initially discussed over $\mathrm{Cu}$ and oxides based catalysts $[19,20]$, which is still debatable. $\mathrm{CO}_{2}$ can adsorb on bare oxides and hydrogen can disassociate on copper species [21]. The active $\mathrm{Cu}$ species is principally present as $\mathrm{Cu}^{0}$ over $\mathrm{Cu}$ / $\mathrm{ZrO}_{2}$ based on X-ray diffraction measurements [22]. However, research group headed by Jansen et al. [23] proposed that $\mathrm{Cu}+$ is the active component for $\mathrm{Cu} / \mathrm{ZnO} / \mathrm{SiO}_{2}$ catalyst employing static low energy ion scatter experiments. Liu et al. [24, 25] suggested that copper metal and low valence of $\mathrm{Cu}\left(\mathrm{Cu}^{+}\right.$and $\left.\mathrm{Cu}^{\delta+}\right)$ may affect the catalytic activity of $\mathrm{Cu}-$ based oxide catalysts. Most recent studies [26-30] declare that resolution of the geometrical and electronic structures of the active site is the first step toward an efficient catalyst design with high selectivity and activity.

The redox mechanism involves the formation of $\mathrm{CO}$ via the Reverse-Water-Gas-Shift (RWGS) reaction and conventional synthesis gas to methanol conversion (Eq. (3)) [31]. As well as, the redox mechanism for the RWGS reaction can be easily modeled through the following scheme:

$$
\begin{aligned}
& \mathrm{CO}_{2}+2 \mathrm{Cu}^{0} \rightarrow \mathrm{Cu}_{2} \mathrm{O}+\mathrm{CO} \\
& \mathrm{H}_{2}+\mathrm{Cu}_{2} \mathrm{O} \rightarrow 2 \mathrm{Cu}^{0}+\mathrm{H}_{2} \mathrm{O}
\end{aligned}
$$

$\mathrm{Cu}^{0}$ atoms are certainly active to disassociate $\mathrm{CO}_{2}$, while the reduction of oxidized $\mathrm{Cu}$ catalyst has to be quicker than the process of oxidation [32,33]. Hence, hydrogen is suggested to be a reducing reagent without direct involvement in the intermediates formation in the reverse-water-gas-shift reaction. The other reaction mechanism is the format decomposition/pathway, where the formation of HCOO intermediate is generally considered to be the rate-determining step [34,35]. According to Tabatabaei et al. [36] the intermediate is a bidentate format on $\mathrm{Cu}$, the most stable absorbed species. Chen et al. [36-40] suggest that $\mathrm{CO}$ is formed from decomposition of format intermediate, deduced from unification of hydrogen $\left(\mathrm{H}_{2}\right)$ with $\mathrm{CO}_{2}$. As well as, Sloczynski et al. [41] indicate that $\mathrm{CO}$ may be formed from decomposition of methanol, whereas the reverse-water-gas-shift mechanism can explain directly the $\mathrm{CO}$ formation as the major by product.

However, a few (critical amount) literatures were revealed on mechanisms for the reaction over Fe-based and oxides catalysts for methanol synthesis from hydrogenation of $\mathrm{CO}_{2}$. Most recent and current research investigations [42-49] on reaction mechanism for Fe-based catalysts have been conducted for hydrocarbon, olefin and methane synthesis from $\mathrm{CO}_{2}$ hydrogenation process.

\subsection{Effect of catalysts on $\mathrm{CO}_{2}$ hydrogenation to methanol}

Since past few decades, many types of catalysts have been examined and investigated for the synthesis of methanol from $\mathrm{CO}_{2}$ hydrogenation. The majority of catalyst for hydrogenation of $\mathrm{CO}_{2}$ contains $\mathrm{Cu}$ as the main component along with different promoters or modifiers ( $\mathrm{Zn}, \mathrm{Zr}, \mathrm{Si}, \mathrm{Al}$, $\mathrm{Ti}, \mathrm{Cr}, \mathrm{Ga}, \mathrm{Ce}$, etc.) [50-52] and literatures on catalytic $\mathrm{CO}_{2}$ hydrogenation process containing $\mathrm{Fe}$ [53] for methanol synthesis have been found a very few. A proper support not only affects the stabilization and formation of the active phase of the catalyst but it is also able to control the interaction between the promoter and major component. Additionally, acidity and basicity characteristics of the catalyst are also determined by the selected support [18].

According to the research conducted by Deerattrakul et al. [54], $10 \mathrm{wt} \% \mathrm{CuZn} / \mathrm{rGO}$ catalyst performed the highest activity for the $\mathrm{CO}_{2}$ hydrogenation with a 26\% $\mathrm{CO}_{2}$ conversion, $51 \% \mathrm{CH}_{3} \mathrm{OH}$ selectivity, and $424 \pm 18 \mathrm{mg}_{\mathrm{MeOH}}$ at $250^{\circ} \mathrm{C}$ and 15 bar after $5 \mathrm{~h}$ on stream of $\mathrm{CO}_{2}$ and $\mathrm{H}_{2}$. When the reaction was completed, the spent catalyst was reevaluated its structure using XRD in order to examine the stability of rGO. The obtained pattern of XRD indicated that the catalyst still had the same structure as that of the initially used catalyst (see Fig. 2). When the loading was increased beyond $10 \mathrm{wt} \%$, the conversion of $\mathrm{CO}_{2}$ and space-time yield of methanol ( $\mathrm{STY}_{\mathrm{MeOH}}$ ) decreased due to the agglomeration of active metals led to reduce copper oxides to metallic $\mathrm{Cu}^{0}$, which is a crucial active metal for synthesis of methanol [54]. As well as, Deerattrakul et al. [54] have mentioned that his results have given the highest $\mathrm{STY}_{\mathrm{MeOH}}$ under the lowest operating pressure comparing to previously published works [55-58]. The rGO reduced by hydrazine played very significant role in the enhanced performance of the $\mathrm{CuZn} /$ rGO catalyst [54]. 


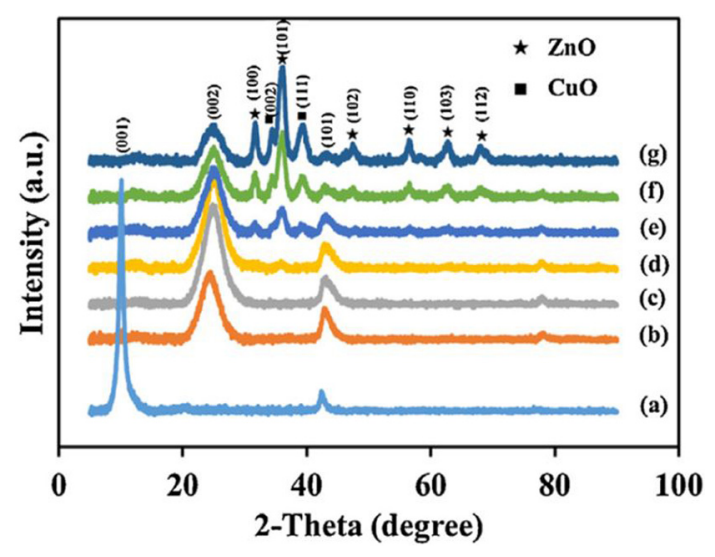

Figure 2

XRD patterns of (a) GO, (b) rGO, (c) calcined rGO, (d) $5 \%$ $\mathrm{CuZn} / \mathrm{rGO}$, (e) $10 \% \mathrm{CuZn} / \mathrm{rGO}$, (f) $20 \% \mathrm{CuZn} / \mathrm{rGO}$ and (g) $30 \% \mathrm{CuZn} / \mathrm{rGO}[54]$.

Liu et al. [58] tested the serials of $\mathrm{Cu}$ catalysts supported on $\mathrm{TiO}_{2}$ modified with different amount of $\mathrm{MgO}$ which were prepared through an impregnation method for synthesis of methanol from $\mathrm{CO}_{2}$ hydrogenation. During experimental investigation, the selectivity of methanol increased first and then decreased with amplifying the amount of $\mathrm{MgO}$. A value of $55 \%$ was obtained over the $\mathrm{Cu} / 5 \%$ supported $\mathrm{MgO}$ modified $\mathrm{TiO}_{2}$ catalyst, which enhanced by $86 \%$ compared with unmodified $\mathrm{Cu} / \mathrm{TiO}_{2}$ catalyst sample. Regarding to $\mathrm{CH}_{3} \mathrm{OH}$ yield, it took on a volcanic variation trend with the addition of $\mathrm{MgO}$, a maximum value of $1.97 \%$ was obtained over the $\mathrm{Cu} / 1 \%$ supported $\mathrm{MgO}$ modified $\mathrm{TiO}_{2}$ catalyst, and the value increased by $54 \%$ comparing to the unmodified $\mathrm{Cu} / \mathrm{TiO}_{2}$ catalyst [58]. This assures that the modification of $\mathrm{TiO}_{2}$ with an accurate amount of $\mathrm{MgO}$ is favorable for the improvement of the $\mathrm{Cu} / \mathrm{TiO}_{2}$ catalytic feature.

Dong et al. [28] applied $\mathrm{Cu} / \mathrm{ZnO} / \mathrm{ZrO}_{2}$ catalyst for $\mathrm{CO}_{2}$ hydrogenation to methanol prepared by precipitationreduction method and reduced by different $\mathrm{NaBH}_{4}$, and the report emphasized that methanol and $\mathrm{CO}$ are the only carbon containing products under the reaction condition. As the catalytic activities for conversion of $\mathrm{CO}_{2}$ increased while $\mathrm{CH}_{3} \mathrm{OH}$ decreased with increasing temperature of reaction from $230^{\circ} \mathrm{C}$ to $270{ }^{\circ} \mathrm{C}$. Basically, increasing temperature promotes the conversion and activation of $\mathrm{CO}_{2}$, however, the $\mathrm{CO}$ production is more conducive than methanol because of the higher activation energy of RWGS reaction and endothermic character [59]. The catalysts prepared by precipitation-reduction method have shown an obvious advantage in methanol selectivity over the conventional $\mathrm{Cu} / \mathrm{ZnO} / \mathrm{ZrO}_{2}$ catalyst, especially at $230{ }^{\circ} \mathrm{C}$. The $\mathrm{CH}_{3} \mathrm{OH}$ selectivity was $66.8 \%$ over $\mathrm{Cu} / \mathrm{ZnO} / \mathrm{ZrO}_{2}-5$ (5-the $\mathrm{NaBH}_{4} / \mathrm{Cu}$ molar ratio) sample at $230{ }^{\circ} \mathrm{C}$, which is $12.7 \%$ higher than $\mathrm{Cu} / \mathrm{ZnO} / \mathrm{ZrO}_{2}-0$ (0-the $\mathrm{NaBH}_{4} / \mathrm{Cu}$

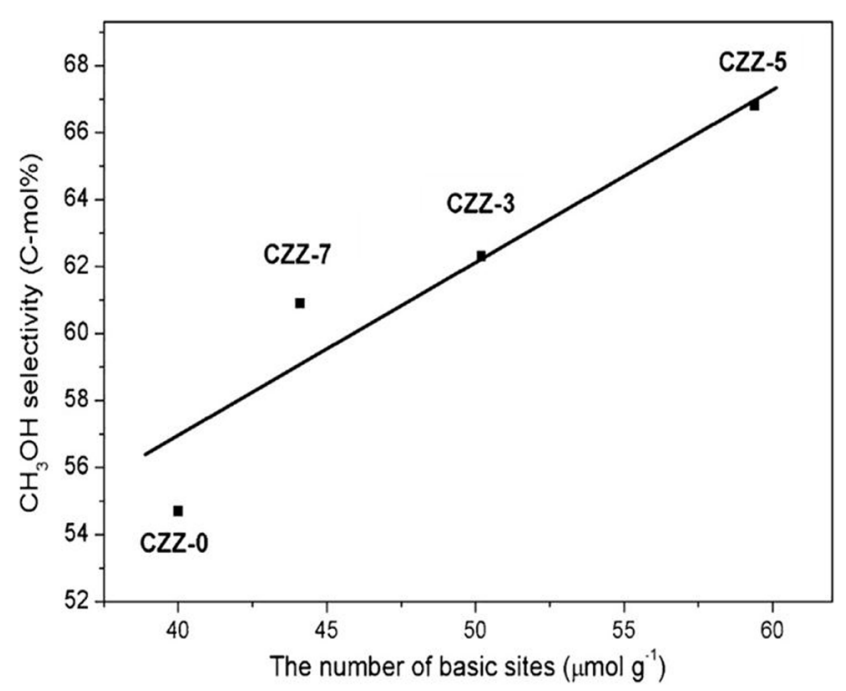

Figure 3

The relationship between $\mathrm{CH}_{3} \mathrm{OH}$ selectivity and the number of basic sites over $\mathrm{Cu} / \mathrm{ZnO} / \mathrm{ZrO}_{2}$ catalysts [28].

molar ratio) sample (see Fig. 3). A maximum STY of $\mathrm{CH}_{3} \mathrm{OH}$ of $0.21 \mathrm{~g} \mathrm{ml}^{-1} \mathrm{~h}^{-1}$ with $\mathrm{CO}_{2}$ conversion of $23 \%$ and methanol selectivity of $56.8 \%$ was obtained over $\mathrm{Cu} /$ $\mathrm{ZnO} / \mathrm{ZrO}_{2}-5$ at $270{ }^{\circ} \mathrm{C}$.

Another example of catalytic $\mathrm{CO}_{2}$ hydrogenation to methanol using $\mathrm{CuO} / \mathrm{ZnO} / \mathrm{Al}_{2} \mathrm{O}_{3}$ catalysts prepared via a solvent-free routine was investigated by Lei et al. [27]. Six CZA (all with the same $\mathrm{Cu} / \mathrm{Zn} / \mathrm{Al}$ atomic ratio of $60 / 25 / 15$ ) prepared using citric acid, oxalic acid or urea as fuel by combustion and mechanical milling method [27]. This research group has also indicated that methanol and $\mathrm{CO}$ were the only carbon containing products under the reaction conditions. With the same fuel/salts molar ratio, CZA-citric acid-1.00 (molar ratio) catalyst performed the highest activity for hydrogenation of $\mathrm{CO}_{2}$ with $14.6 \%$ conversion of $\mathrm{CO}_{2}$, perhaps because of the larger exposed $\mathrm{Cu}$ surface area and smaller particle size. The calculated STY of methanol reached $0.12 \mathrm{~g}_{\mathrm{MeOH}} /\left(\mathrm{g}_{\mathrm{cat}} \mathrm{h}\right)$, while the conversion of $\mathrm{CO}_{2}$ and STY of methanol decreased to $12.1 \%$ and $0.1 \mathrm{~g}_{\mathrm{MeOH}} /\left(\mathrm{g}_{\text {cat }} \mathrm{h}\right)$ over CZA-oxalic acid-1.00. CZA-urea-1.00 has shown the lowest activity for hydrogenation of $\mathrm{CO}_{2}$ with $3.2 \% \quad \mathrm{CO}_{2}$ conversion and $0.022 \mathrm{~g}_{\mathrm{MeOH}} /\left(\mathrm{g}_{\mathrm{cat}} \mathrm{h}\right) \mathrm{STY}_{\mathrm{MeOH}}$, which could be resulted to the smaller exposed $\mathrm{Cu}$ surface area and larger particle size of $\mathrm{CuO}$, and the formation of $\mathrm{ZnAl}_{2} \mathrm{O}_{4}$ [27]. Consequently, it was revealed that the $\mathrm{CO}_{2}$ conversion and STY of methanol increased with the added amount of citric acid during catalyst preparation and the maximum conversion of $\mathrm{CO}_{2}$ reached $16.2 \%$ over CZA-citric acid1.25. Additionally, from above mentioned results, it can be inferred that $\mathrm{Cu}$ surface area is also one of the essential parameter for $\mathrm{Cu} / \mathrm{Zn} / \mathrm{Al}_{2} \mathrm{O} 3$ catalysts since it is related tightly to the catalytic activity of catalysts (see Fig. 4). 


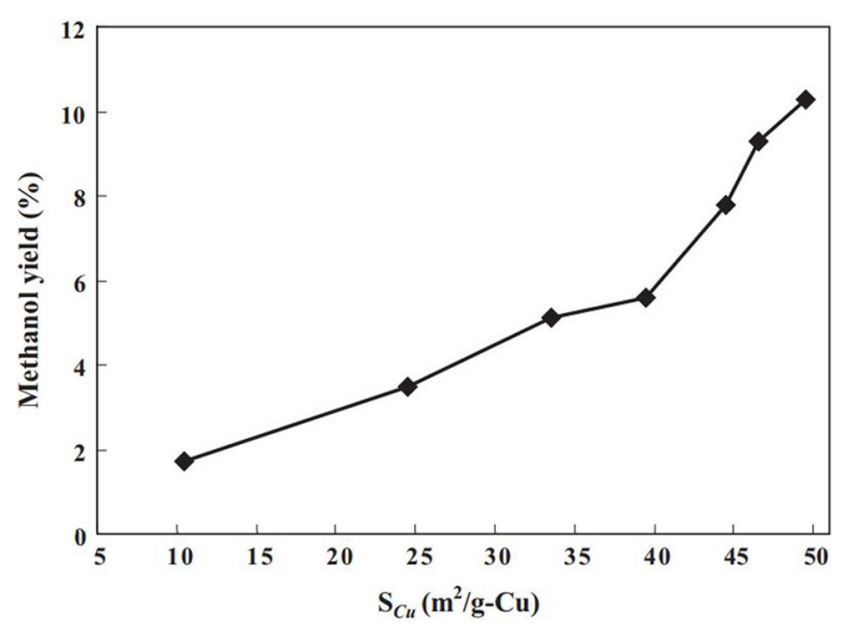

Figure 4

The relationship between methanol yield and the exposed $\mathrm{Cu}$ surface area (reaction conditions: $\mathrm{H}_{2} / \mathrm{CO}_{2}=3, T=240^{\circ} \mathrm{C}$, $P=3.0 \mathrm{MPa}$, GHSV $=3600 \mathrm{~h}^{-1}$ ) [27].

Regarding to Fe-based catalysts, Dorner et al. [60] report that low loading of ceria to a $\mathrm{Fe}-\mathrm{Mn} / \mathrm{Al}_{2} \mathrm{O}_{3}$ catalyst leads to a marginal improvement in conversion of $\mathrm{CO}_{2}$ and products selectivity, a decrease in reactivity was observed when the doping amount was increased to $10 \mathrm{wt} \%$. Other additives such as $\mathrm{Zn}, \mathrm{Mg}, \mathrm{Ru}, \mathrm{Zr}$, and La have also been researched but promoting effect is nearly inappreciable [53,61-63]. Iron based catalysts dispersed on various supports have also been tested extensively and the product distributions are highly dependent on supporting materials [53]. The support tends to act completely as a stabilizer to avoid sintering of active particles during the reaction process. Usually, alumina executes efficiently, since it could prevent sintering as a result of the stable interaction or metal support, followed by titania and silica [53, 64, 65]. Dorner et al. [60] reported that the addition of ceria to a $\mathrm{Fe} / \mathrm{Mn}-\mathrm{Al}_{2} \mathrm{O}_{3}$ catalyst leaded to a marginal improvement in conversion of $\mathrm{CO}_{2}$ and product selectivity at low Ce-levels ( $2 \mathrm{wt} \%$ ). During heavier doping, the effect of $\mathrm{Ce}$ on the overall conversion of $\mathrm{CO}_{2}$ is decreased, with $14 \%$ loss in the yield. Ceria forms on top of the Fe particles, leaded to the blocking of the chain-growth sites during hydrogenation of $\mathrm{CO}_{2}$, in the result, $\mathrm{CO}_{2}$ is instead converted to $\mathrm{CO}$, that desorbs without being converted to valued-added products as a the chain-growth active site concentration has been decreased by the heavier doping of ceria. This is due to the fact that the chain-growth probability is not affected between the ceria-free and ceria containing catalyst [60]. According to Dubois et al. [66] investigation, hydrogenation of $\mathrm{CO}_{2}$ using transitional metal carbides, such as $\mathrm{Fe}_{3} \mathrm{C}$ and $\mathrm{Mo}_{2} \mathrm{C}$ indicated high conversion of $\mathrm{CO}_{2}$ and methanol selectivity at $220^{\circ} \mathrm{C}$. Nevertheless, more particular literature on comprehensive application of iron based catalyst for methanol synthesis from $\mathrm{CO}_{2}$ hydrogenation is still not sufficient and hence more profound scientific research is suggested to discover the hidden potential catalytic features Fe-based catalyst for methanol synthesis from hydrogenation of $\mathrm{CO}_{2}$.

The catalysts with high efficiency are the key for synthesis of methanol through hydrogenation of $\mathrm{CO}_{2}$. So far, comprehensive application of catalysts on industrial scale is still not fully satisfying due to the insufficient of the necessary knowledge in designing of catalysts for the mechanistic perception of $\mathrm{CO}_{2}$ hydrogenation and control of relevant catalytic properties.

\subsection{Effect of operating parameters on $\mathrm{H}_{2} / \mathrm{CO}_{2}$ to methanol}

In this section the effect of operating parameters on $\mathrm{H}_{2} / \mathrm{CO}_{2}$ to methanol has been evaluated based on the previous experimental investigations with the results as shown in Table 1 . The table summarizes the effect type of catalysts, temperature, pressure and type of reactor on $\mathrm{CO}_{2}$ conversion $(\%), \mathrm{MeOH}$ selectivity (\%), $\mathrm{MeOH}$ yield (\%) and STY of $\mathrm{MeOH}\left(\mathrm{g}_{\mathrm{MeOH}} / \mathrm{g}_{\text {cat }} \mathrm{h}\right)$.

\section{RECENT TECHNOLOGICAL AND INDUSTRIAL ADVANCES}

The first pilot plant capacity of $50 \mathrm{~kg} / \mathrm{h}$ for methanol production from $\mathrm{CO}_{2}$ and $\mathrm{H}_{2}$ was constructed in 1996 in Japan with application of $\mathrm{SiO}_{2}$-modified $\mathrm{CuO} / \mathrm{ZnO}$ catalyst. Recycling the feed extracted a STY of methanol yield approximately $600 \mathrm{~g} /(\mathrm{L} \mathrm{h})$, with selectivity of $99.9 \%$ over $8000 \mathrm{~h}$ under operating conditions $T=250^{\circ} \mathrm{C}$ and $5 \mathrm{MPa}$ [71]. According to Tremblay [72], another pilot plant for production of methanol from $\mathrm{CO}_{2}$ and $\mathrm{H}_{2}$ with yearly capacity of 100 tones is partially built by Mitsui Chemicals, Japan. In order to completely accomplish the construction and meet the target, $\mathrm{H}_{2}$ will be generated via photochemical water splitting using solar energy [72]. Since 2010, this particular pilot plant of Mitsui Chemicals is under use at the R\&D sites (Osaka Works) and currently synthesizes methanol, later used in the production of olefins, ethylene oxide, ethylene glycol and aromatics, using the $\mathrm{CO}_{2}$ emitted from factories and hydrogen obtained from water photolysis. One of the main millstones was achieved by Sud-Chemie and Lurgi AG institutions, they together developed a highly selective and active catalyst for methanol production from $\mathrm{CO}_{2}$ and $\mathrm{H}_{2}$ at temperature $260^{\circ} \mathrm{C}$ [73]. Air Products Liquid Phase Conversion Company for the US DOE National Energy Technology Laboratory reported that for the first time, a liquid-phase synthesis of methanol was also developed, which is able to convert $\mathrm{CO}_{2}$ and $\mathrm{H}_{2}$ into methanol of nearby $95 \%$ with immensely high selectivity in a single pass. As stated by 
Table 1

Summary of the effect of operating parameters on $\mathrm{H}_{2} / \mathrm{CO}_{2}$ to methanol.

\begin{tabular}{|c|c|c|c|c|c|c|c|}
\hline Type of catalyst & Type of reactor & $\begin{array}{l}T\left({ }^{\circ} \mathrm{C}\right) / \\
\mathrm{P}(\mathrm{MPa})\end{array}$ & $\begin{array}{l}\mathrm{CO}_{2} \\
\text { conversion (\%) }\end{array}$ & $\begin{array}{l}\mathrm{MeOH} \\
\text { selectivity (\%) }\end{array}$ & $\begin{array}{l}\mathrm{MeOH} \\
\text { yield (\%) }\end{array}$ & $\begin{array}{l}\text { STY of } \mathrm{MeOH} \\
\left(\mathrm{g}_{\mathrm{MeOH}} / \mathrm{g}_{\mathrm{cat}} \mathrm{h}\right)\end{array}$ & Ref \\
\hline $\mathrm{CuO}-\mathrm{Fe}_{2} \mathrm{O}_{3}-3 \% \mathrm{CeO}_{2} / \mathrm{HZSM}-5$ & Fixed-bed & $260 / 3$ & 20.9 & 5.2 & $\mathrm{~N} / \mathrm{A}$ & N/A & [8] \\
\hline $\mathrm{CuO}-\mathrm{Fe}_{2} \mathrm{O}_{3}-4 \% \mathrm{CeO}_{2} / \mathrm{HZSM}-5$ & Fixed-bed & $260 / 3$ & 17.1 & 4.6 & N/A & N/A & [8] \\
\hline $\mathrm{CuO} / \mathrm{ZnO} / \mathrm{Al}_{2} \mathrm{O}_{3}-\mathrm{C}-1$ & Fixed-bed & $240 / 3$ & 14.6 & 63.6 & 9.3 & 0.12 & [27] \\
\hline $\mathrm{CuO} / \mathrm{ZnO} / \mathrm{Al}_{2} \mathrm{O}_{3}-\mathrm{C}-1.25$ & Fixed-bed & $240 / 3$ & 16.2 & 63.8 & 10.3 & 0.13 & [27] \\
\hline $\mathrm{CuO} / \mathrm{ZnO} / \mathrm{Al}_{2} \mathrm{O}_{3}-\mathrm{O}-1$ & Fixed-bed & $240 / 3$ & 12.1 & 62.6 & 7.8 & 0.10 & [27] \\
\hline $\mathrm{CuO} / \mathrm{ZnO} / \mathrm{Al}_{2} \mathrm{O}_{3}-\mathrm{U}-1$ & Fixed-bed & $240 / 3$ & 3.2 & 53.9 & 1.7 & 0.022 & [27] \\
\hline $\mathrm{Cu} / \mathrm{ZnO} / \mathrm{ZrO}_{2}-0$ & Fixed-bed & $230 / 5$ & 16.7 & 54.7 & N/A & 0.14 & [28] \\
\hline $\mathrm{Cu} / \mathrm{ZnO} / \mathrm{ZrO}_{2}-5$ & Fixed-bed & $230 / 5$ & 15.4 & 66.8 & N/A & 0.16 & [28] \\
\hline $\mathrm{Cu} / \mathrm{ZnO} / \mathrm{ZrO}_{2}-0$ & Fixed-bed & $270 / 5$ & 22.5 & 51.8 & N/A & 0.18 & [28] \\
\hline $\mathrm{Cu} / \mathrm{ZnO} / \mathrm{ZrO}_{2}-5$ & Fixed-bed & $270 / 5$ & 23.0 & 56.8 & N/A & 0.21 & [28] \\
\hline $5 \% \mathrm{CuZn} / \mathrm{rGO}$ & Fixed-bed & $250 / 1.5$ & 14 & 2.8 & N/A & 0.22 & [54] \\
\hline $10 \% \mathrm{CuZn} / \mathrm{rGO}$ & Fixed-bed & $250 / 1.5$ & 26 & 5.1 & N/A & 0.424 & [54] \\
\hline $20 \% \mathrm{CuZn} / \mathrm{rGO}$ & Fixed-bed & $250 / 1.5$ & 19 & 8.5 & N/A & 0.244 & [54] \\
\hline $\mathrm{CuZnGa}$ & Fixed-bed & $270 / 3$ & 15.8 & N/A & 29.3 & 0.135 & [55] \\
\hline $\mathrm{Cu} / 0.5 \% \mathrm{MgO} / \mathrm{TiO}_{2}$ & Fixed-bed & $220 / 3$ & 5.0 & 33.9 & 1.70 & N/A & [58] \\
\hline $\mathrm{Cu} / 1 \% \mathrm{MgO} / \mathrm{TiO}_{2}$ & Fixed-bed & $220 / 3$ & 5.2 & 37.9 & 1.97 & N/A & [58] \\
\hline $\mathrm{Cu} / 5 \% \mathrm{MgO} / \mathrm{TiO}_{2}$ & Fixed-bed & $220 / 3$ & 2.6 & 55.5 & 1.44 & N/A & [58] \\
\hline $\mathrm{Cu} / \mathrm{TiO}_{2}$ & Fixed-bed & $220 / 3$ & 4.3 & 29.8 & 1.28 & N/A & [58] \\
\hline $\mathrm{Cu}-\mathrm{Zn} / \mathrm{SiO}_{2}$ & Fixed-bed & $250 / 2$ & 2.0 & 65.7 & N/A & 0.065 & [67] \\
\hline $10 \mathrm{Cu} 60 \mathrm{Zn} 30$ & Fixed-bed & $250 / 1.5$ & 21 & 83 & N/A & 0.274 & [68] \\
\hline $\mathrm{Fe}-\mathrm{Cu} / \mathrm{MCM}-41$ & Fixed-bed & $200 / 1$ & 2 & 80 & N/A & N/A & [69] \\
\hline $\mathrm{Cu}-\mathrm{ZnO} / \mathrm{TiO}_{2}-\mathrm{ZrO}_{2}$ & Fixed-bed & $240 / 3$ & 17.4 & 43.8 & 7.6 & 0.053 & [70] \\
\hline
\end{tabular}

Shulenberger et al. [74], the first commercial $\mathrm{CO}_{2}$ into methanol recycling plant by using indigenously available inexpensive geothermal energy is currently under construction after felicitous pilot plant operation by the Carbon Recycling International Company in Iceland. This particular plant called "Emissions-to-Liquids" is based on $\mathrm{CO}_{2}$ conversion to vital by-products via integrated applications of indigenous industrial or geothermal energy sources, and hydrogen is produced via electrolysis of water [74]. Currently, the emissions-to-liquids methanol plant with nominal $50000 \mathrm{ton} / \mathrm{yr}$ methanol production capacity is under operation and is designed to utilize existing sources of clean $\mathrm{CO}_{2}$ or to process carbon dioxide from an emission sources, and is also constructed to produce its own $\mathrm{H}_{2}$ feedstock from electrolysis or to utilize by-product hydrogen from another industrial process. The technological practicability of methanol production from $\mathrm{CO}_{2}$ has also been highlighted in pilot plant applying two-step mechanistic approach, process reverse water-gas-shift separate from synthesis of methanol or single-step mechanistic approach (the two stages combined in a single reactor) [16]. However, Centi and Perathoner [16] allege that the first mechanistic approach is preferential due to greater catalyst productivity, lower reactor size and gas recycles.

Since 2015, research scientists at the Laboratory of Nanochemisty and Ecology, National University of Science and Technology (MIS\&S) in Moscow (Russia), have been donating massive efforts in development of novel nanosized, hetero and homogeneous catalysts to activate $\mathrm{CO}_{2}$ $[75,76]$ in a reasonable, economically and ecologically efficient process for methanol production. Undoubtedly, all these extensive developments are immensely stimulating factors for sustainable development and for improvement of our environment. 


\section{CONCLUSION}

Present work comprehensively highlighted recent advances in catalytic hydrogenation of $\mathrm{CO}_{2}$ to methanol. From the research survey, it is inferred that a great number of catalytic studies on methanol synthesis from $\mathrm{CO}_{2}$ hydrogenation have been focused on catalytic activities of $\mathrm{Cu}$-based catalysts, while Fe-based catalysts indicated a contrary tendency. $\mathrm{Cu}-$ based catalysts along with various efficient promoters (e.g. Al, $\mathrm{Ga}, \mathrm{Si}, \mathrm{Zr}$, etc.) are considerably useful. Accurately selected promoters and supports enhance the activity, stability and selectivity of the catalyst. Except promoters and support, higher surface area and smaller particle size of catalyst are considered as one of the most crucial factors for higher methanol yield production from hydrogenation of $\mathrm{CO}_{2}$.

Although several efforts have been made to upgrade and modify the technological progress of methanol synthesis from hydrogenation of $\mathrm{CO}_{2}$, the greatly effective process to enhance the conversion of $\mathrm{CO}_{2}$ is still pursued because of the thermodynamically stable nature of carbon dioxide molecule. Detailed research investigations on the catalyst sensitivities to admixtures, catalysts reaction performance under complex conditions are required. Moreover, the robust mechanism for synthesis of methanol from $\mathrm{CO}_{2}$ hydrogenation is not yet completely understood. As well as, as conversion of $\mathrm{CO}_{2}$ into value-added products or chemicals requires energy in the form of hydrogen or heat, alternative energy like biomass, wind, solar, geothermal and nuclear energy, is recommended to be applied instead of fossil fuel during conversion process. Besides, the future scientific undertaking have to focus to develop more highly efficient and "smart" catalysts, mechanisms and integrated process technology to encounter not only economic but also environmental challenges and to promote bio-based "green" economy.

\section{ACKNOWLEDGMENTS}

The authors gratefully acknowledge the financial support of the Ministry of Education and Science of the Russian Federation in the framework of Increase Competitiveness Program of NUST «MISiS» (No. K4-2016-054), implemented by a governmental decree dated 16th March 2013, N 211.

\section{REFERENCES}

1 Friedlingstein P., Andrew R.M., Rogelj J., Peters G.P., Ganadell J.G., Knutti R., Luderer G., Raupach M.R., Schaeffer M., van Vuuren D.P., Le Quere C. (2014) Persistent growth of $\mathrm{CO}_{2}$ emissions and implications for reaching climate targets, J. Nat. Geosci. 7, 709-715.

2 Metz B., Davidson O.R., Bosch P.R., Meyer L.A. (eds.) (2007) Climate Change 2007: Mitigation of Climate Change, Cambridge University Press, Cambridge, United Kingdom and New York, NY, USA.
3 Hu B., Guild C., Suib S.L. (2013) Thermal, electrochemical, and photochemical conversion of $\mathrm{CO}_{2}$ to fuels and value-added products, $\mathrm{J}_{\mathrm{C}} \mathrm{CO}_{2}$ Util. 1, 18-27.

4 Bachu S. (2008) $\mathrm{CO}_{2}$ storage in geological media: role, means, status and barriers to deployment, J. Progr. Energy Combust. Sci. 34, 254-273.

5 Song C. (2006) Global challenges and strategies for control, conversion and utilization of $\mathrm{CO}_{2}$ for sustainable development involving energy, catalysis, adsorption and chemical processing, J. Catal. Today 115, 2-32.

6 Duong X., Li F., Zhao N., Xiao F., Wang J., Tan Y. (2016) $\mathrm{CO}_{2}$ hydrogenation to methanol over $\mathrm{Cu} / \mathrm{ZnO} / \mathrm{ZrO}_{2}$ catalysts prepared by precipitation-reduction method, J. Appl. Catal. B: Environ. 191, 8-17.

7 Angelo L., Kobl K., Tejada L.M.M., Zimmermann Y., Parkhomenko K., Roger A.C. (2015) Study of $\mathrm{CuZnMO}_{x}$ oxides $(\mathrm{M}=\mathrm{Al}, \mathrm{Zr}, \mathrm{Ce}, \mathrm{CeZr})$ for the catalytic hydrogenation of $\mathrm{CO}_{2}$ into methanol, J. C. R. Chimie 18, 250-260.

8 Zhou X., Su T., Jiang Y., Qin Z., Ji H., Guo Z. (2016) CuO$\mathrm{Fe}_{2} \mathrm{O}_{3}-\mathrm{CeO}_{2} / \mathrm{HZSM}-5$ bifunctional catalyst hydrogenated $\mathrm{CO}_{2}$ for enhanced dimethyl ether synthesis, J. Chem. Eng. Sci. 153, 10-20.

9 Aresta M., Dibenedetto A., Angelini A. (2013) The changing paradigm in $\mathrm{CO}_{2}$ utilization, $J . \mathrm{CO}_{2}$ Util. 3-4, 65-73.

10 Olah G.A., Prakash G.K.S., Goeppert A. (2011) Anthropogenic chemical carbon cycle for a sustainable future, J. Am. Chem. Soc. 133, 12881-12898.

11 Bansode A., Tidona B., von Rohr P.R., Urakawa A. (2013) Impact of $\mathrm{K}$ and $\mathrm{Ba}$ promoters on $\mathrm{CO}_{2}$ hydrogenation over $\mathrm{CU} /$ $\mathrm{Al}_{2} \mathrm{O}_{3}$ catalysts at high pressure, J. Catal. Sci. Technol. 3, 767-778.

12 Inui T., Takeguchi T. (1991) Effective conversion of carbon dioxide and hydrogen to hydrocarbons, J. Catal. Today 10, 95-106.

13 Li Y., Ma R., He L., Diao Z. (2014) Homogeneous hydrogenation of carbon dioxide to methanol, J. Catal. Sci. Technol. 4, 1498-1512.

14 Dai W.L., Luo S.L., Yin S.F., Au C.T. (2009) The direct transformation of carbon dioxide to organic carbonates over heterogeneous catalysts, J. Appl. Catal. A 366, 2-12.

15 Mikkelsen M., Jorgensen M., Krebs F.C. (2010) The teraton challenge. A review of fixation and transformation of carbon dioxide, J. Energy Environ. Sci. 3, 43-81.

16 Centi G., Perathoner S.J. (2009) Opportunities and prospects in the chemical recycling of carbon dioxide to fuels, J. Catal. Today 148, 191-205.

17 Zhang S., Chen Y., Li F., Lu X., Dai W., Mori R.J. (2006) Fixation and conversion of $\mathrm{CO}_{2}$ using ionic liquids, J. Catal. Today 115, 61-69.

18 Liu X., Lu G.Q., Yan Z., Beltramini J. (2003) Recent advances in catalysts for methanol synthesis via hydrogenation of $\mathrm{CO}$ and $\mathrm{CO}_{2}$, J. Ind. Eng. Chem. Res. 42, 6518-6530.

19 Schild C., Wokaun A. (1990) On the mechanism of CO and $\mathrm{CO}_{2}$ hydrogenation reactions on zirconia-supported catalysts: a diffuse reflectance FTIR study: Part II. Surface species on copper/zirconia catalysts: implications for methanol synthesis selectivity, J. Mol. Catal. 63, 243-254.

20 Borodko Y., Somorjai G.A. (1999) Catalytic hydrogenation of carbon oxides - a 10-year perspective, J. Appl. Catal. A 186, 355-362.

21 Fisher I.A., Bell A.T. (1997) In-situ infrared study of methanol synthesis from $\mathrm{H}_{2} / \mathrm{CO}_{2}$ over $\mathrm{Cu} / \mathrm{SiO}_{2}$ and $\mathrm{Cu} / \mathrm{ZrO}_{2} / \mathrm{SiO}_{2}, J$. Catal. 172, 222-237. 
22 Koeppel R.A., Baiker A. (1992) Copper/zirconia catalysts for the synthesis of methanol from carbon dioxide: influence of preparation variables on structural and catalytic properties of catalysts, J. Appl. Catal. A 84, 77-102.

23 Jansen W.P.A., Beckers J., Heuvel J.C., Denier A.W., Bliek A., Brongersma H.H. (2002) Dynamic behavior of the surface structure of $\mathrm{Cu} / \mathrm{ZnO} / \mathrm{SiO}_{2}$ catalysts, J. Catal. 210, 229-236.

24 Liu X.M., Lu G.Q., Yan Z.F. (2005) Nanocrystalline zirconia as catalyst support in methanol synthesis, J. Appl. Catal. A 279, 241-245.

25 Liu S.H., Wang H.P., Wang H.C., Yang Y.W. (2005) In situ EXAFS studies of copper on $\mathrm{ZrO}_{2}$ during catalytic hydrogenation of $\mathrm{CO}_{2}$, J. Electron Spectrosc. Relat. Phenom. 144147, 373-376.

26 Tang Q.L., Hong Q.J., Liu Z.P. (2009) $\mathrm{CO}_{2}$ fixation into methanol at $\mathrm{Cu} / \mathrm{ZrO}_{2}$ interface from first principles kinetic Monte Carlo, J. Catal. 263, 114-122.

27 Lei H., Hou Z., Xie J. (2016) Hydrogenation of $\mathrm{CO}_{2}$ to $\mathrm{CH}_{3} \mathrm{OH}$ over $\mathrm{CuO} / \mathrm{ZnO} / \mathrm{Al}_{2} \mathrm{O}_{3}$ catalysts prepared via a solvent-free routine, J. Fuel 164, 191-198.

28 Dong X., Li F., Zhao N., Xiao F., Wang J., Tan Y. (2016) $\mathrm{CO}_{2}$ hydrogenation to methanol over $\mathrm{Cu} / \mathrm{ZnO} / \mathrm{ZrO}_{2}$ catalysts prepared by precipitation-reduction method, J. Appl. Catal. B 191, 8-17.

29 Zhou X., Su T., Jiang Y., Qin Z., Ji H. (2016) $\mathrm{CU}-\mathrm{Fe}_{2} \mathrm{O}_{3}-$ $\mathrm{CeO}_{2} / \mathrm{HZSM}-5$ bifunctional catalyst hydrogenated $\mathrm{CO}_{2}$ for enhanced dimethyl ether synthesis, J. Chem. Eng. Sci. 153, 10-20.

30 Silva R.J., Pimentel A.F., Monteiro R.S., Mota J.A. (2016) Synthesis of methanol and dimethyl ether from the $\mathrm{CO}_{2}$ hydrogenation over $\mathrm{Cu}-\mathrm{ZnO}$ supported on $\mathrm{Al}_{2} \mathrm{O}_{3}$ and $\mathrm{Nb}_{2} \mathrm{O}_{5}$, J. $\mathrm{CO}_{2}$ Util. 15, 83-88.

31 Weigel J., Koeppel R.A., Baiker A., Wokaun A. (1996) Surface Species in $\mathrm{CO}$ and $\mathrm{CO}_{2}$ hydrogenation over copper/zirconia: on the methanol synthesis mechanism, J. Langmuir 12, 53195329.

32 Fujita S.I., Usui M., Takezawa N. (1992) Mechanism of the reverse water gas shift reaction over $\mathrm{Cu} / \mathrm{ZnO}$ catalyst, J. Catal. 134, 220-225.

33 Gines M.J.L., Marchi A.J., Apesteguia C.R. (1997) Kinetic study of the reverse water-gas shift reaction over $\mathrm{CuO} / \mathrm{ZnO} /$ $\mathrm{Al}_{2} \mathrm{O}_{3}$ catalysts, J. Appl. Catal. A 154, 155-171.

34 Chiavassa D.L., Collins S.E., Bonivardi A.L., Baltanas M.A. (2009) Methanol synthesis from $\mathrm{CO}_{2} / \mathrm{H}_{2}$ using $\mathrm{Ga}_{2} \mathrm{O}_{3}-\mathrm{Pd} /$ silica catalysts: kinetic modeling, J. Chem. Eng. 150, 204-212.

35 Lim H.W., Park M.J., Kang S.H., Chae H.J., Bae J.W., Jun K. W. (2009) Modeling of the kinetics for methanol synthesis using $\mathrm{Cu} / \mathrm{ZnO} / \mathrm{Al}_{2} \mathrm{O}_{3} / \mathrm{ZrO}_{2}$ catalyst: influence of carbon dioxide during hydrogenation, J. Ind. Eng. Chem. Res. 48, 10448-10455.

36 Chen C.S., Cheng W.H., Lin S.S. (2000) Mechanism of CO formation in reverse water-gas shift reaction over $\mathrm{Cu} / \mathrm{Al}_{2} \mathrm{O}_{3}$ catalyst, J. Catal. Lett. 68, 45-48.

37 Chen C.S., Cheng W.H., Lin S.S. (2002) Study of reverse water gas shift reaction by TPD, TPR and $\mathrm{CO}_{2}$ hydrogenation over potassium-promoted $\mathrm{Cu} / \mathrm{SiO}_{2}$ catalyst, J. Appl. Catal. A 238, $55-67$.

38 Chen C.S., Cheng W.H., Lin S.S. (2004) Study of ironpromoted $\mathrm{Cu} / \mathrm{SiO}_{2}$ catalyst on high temperature reverse water gas shift reaction, J. Appl. Catal. A 257, 97-106.

39 Chen C.S., Wu J.H., Lai T.W. (2010) Carbon dioxide hydrogenation on $\mathrm{Cu}$ nanoparticles, J. Phys. Chem. 114, 15021-12028.
40 Chen C., Ruan C., Zhan Y., Lin X., Zheng Q., Wei K. (2014) The significant role of oxygen vacancy in $\mathrm{Cu} / \mathrm{ZrO}_{2}$ catalyst for enhancing water-gas-shift performance, Int. J. Hydrog. Energy 39, 317-324.

41 Sloczynski J., Grabowski R., Kozlowska A., Olszewski P., lachowska M., Skrzypek J., Stoch J. (2003) Effect of Mg and $\mathrm{Mn}$ oxide additions on structural and adsorptive properties of $\mathrm{Cu} / \mathrm{ZnO} / \mathrm{ZrO}_{2}$ catalysts for the methanol synthesis from $\mathrm{CO}_{2}$, J. Appl. Catal. A 249, 129-138.

42 Nam S.S., Kim H., Kisham G., Choi M.J., Lee K.W. (1999) Catalytic conversion of carbon dioxide into hydrocarbons over iron supported on alkali ion-exchanged Y-zeolite catalysts, J. Appl. Catal. A 179, 155-163.

43 Bakavoli M., Zamani Y., Akbarzadeh M. (2014) Study on the carbon dioxide hydrogenation to hydrocarbons over nanoparticles iron-based catalyst, J. Petrol. Coal. 56, 480-486.

44 Kiatphuengporn S., Jantaratana P., Limtrakul J., Chareonpanich M. (2016) Magnetic field-enhanced catalytic $\mathrm{CO}_{2}$ hydrogenation and selective conversion to light hydrocarbons over Fe/MCM-41 catalysts, J. Chem. Eng. 306, 866-875.

45 Visconti C.C., Martinelli M., Falbo L., Fratalocchi L., Lietti L. (2016) $\mathrm{CO}_{2}$ hydrogenation to hydrocarbons over $\mathrm{Co}$ and $\mathrm{Fe}-$ based Fischer-Tropsch catalysts, J. Catal. Today 277, 161-170.

46 Fischer N., Henkel R., Hettel B., Iglesias M., Schaub G., Claeys M. (2016) Hydrocarbons via $\mathrm{CO}_{2}$ hydrogenation over iron catalysts: the effect of potassium on structure and performance, J. Catal. Lett. 146, 509-517.

47 Visconti C.G., Martinelli M., Falbo L., Molina A.I., Lietti L., Forzatti P., Iaquaniello G., Palo E., Picutti B., Brignoli F. (2016) $\mathrm{CO}_{2}$ hydrogenation to lower olefins on a high surface area K-promoted bulk Fe-catalyst, J. Appl. Catal. B 200, 530-542.

48 Hu S., Liu M., Ding F., Song Ch., Zhang G., Guo X. (2016) Hydrothermally stable MOFs for $\mathrm{CO}_{2}$ hydrogenation over iron-based catalyst top light olefins, J. $\mathrm{CO}_{2}$ Util. 15, 89-95.

49 Kangvansura P., Chew L.M., Saengsui W., Santawaja P., Pooarporn Y., Muhler M., Schulz H., Worayingyong A. (2016) Product distribution of $\mathrm{CO}_{2}$ hydrogenation by K- and Mnpromoted Fe catalysts supported on $N$-functionalized carbon nanotubes, J. Catal. Today 275, 59-65.

50 Zhang L.X., Zhang Y.C., Chen S.Y. (2011) Effect of promoter $\mathrm{TiO}_{2}$ on the performance of $\mathrm{CuO}-\mathrm{ZnO}-\mathrm{Al}_{2} \mathrm{O}_{3}$ catalyst for $\mathrm{CO}_{2}$ catalytic hydrogenation to methanol, J. Fuel Chem. Technol. 39, 912-917.

51 Huang Ch., Chen Sh., Fei X., Liu D., Zhang Y. (2015) Catalytic hydrogenation of $\mathrm{CO}_{2}$ to methanol: study of synergistic effect on adsorption properties of $\mathrm{CO}_{2}$ and $\mathrm{H}_{2}$ in $\mathrm{CuO} / \mathrm{ZnO} / \mathrm{ZrO}_{2}$ system, J. Catal. 5, 1846-1861.

52 Liaw B.J., Chen Y.Z. (2001) Liquid-phase synthesis of methanol from $\mathrm{CO}_{2} / \mathrm{H}_{2}$ over ultrafine CuB catalysts, J. Appl. Catal. A 206, 245-256.

53 Prasad P.S.S., Bae J.W., Jun K.W., Lee K.W. (2008) FischerTropsch synthesis by carbon dioxide hydrogenation on $\mathrm{Fe}-$ based catalysts, Catal. Surv. Asia 12, 170-183.

54 Deerattrakul V., Dittanet P., Sawangphruk M., Kongkachuichay P. (2016) $\mathrm{CO}_{2}$ hydrogenation to methanol using $\mathrm{Cu}-\mathrm{Zn}$ catalyst supported on reduced grapheme oxide nanosheets, $J$. $\mathrm{CO}_{2}$ Util. 16, 104-113.

55 Cai W., Piscina P.R., Toyir J., Homs N. (2015) $\mathrm{CO}_{2}$ hydrogenation to methanol over $\mathrm{CuZnGa}$ catalysts prepared using microwave-assisted methods, J. Catal. Today 242, 193-199. 
56 Ren H., Xu Ch.H., Zhao H.Y., Wang Y.X., Liu J., Liu J.Y. (2015) Methanol synthesis from $\mathrm{CO}_{2}$ hydrogenation over $\mathrm{Cu}$ / $\gamma-\mathrm{Al}_{2} \mathrm{O}_{3}$ catalysts modified by $\mathrm{ZnO}, \mathrm{ZrO}_{2}$ and $\mathrm{MgO}, J$. Ind. Eng. Chem. 28, 261-267.

57 Jeong H., Cho C.H., Kim T.H. (2012) Effect of Zr and pH in the preparation of $\mathrm{Cu} / \mathrm{ZnO}$ catalysts for the methanol synthesis by $\mathrm{CO}_{2}$ hydrogenation, React. Kinet. Mech. Catal. 106, 435-443.

58 Liu Ch., Guo X., Guo Q., Mao D., Yu J., Lu G. (2016) Methanol synthesis from $\mathrm{CO}_{2}$ hydrogenation over copper supported on MgO-modified $\mathrm{TiO}_{2}$, J. Mol. Catal. A 425, 86-93.

59 Guo X., Mao D., Lu G., Wang S., Wu G. (2010) Glycine-nitrate combustion synthesis of $\mathrm{CuO}-\mathrm{ZnO}-\mathrm{ZrO}_{2}$ catalysts for methanol synthesis from $\mathrm{CO}_{2}$ hydrogenation, J. Catal. 271, 178-185.

60 Dorner R.W., Hardy D.R., Williams F.W., Willauer H.D. (2010) Effects of ceria-doping on a $\mathrm{CO}_{2}$ hydrogenation ironmanganese catalyst, J. Catal. Commun. 11, 816-819.

61 Ning W., Koizumi N., Yamada M. (2009) Researching Fe catalyst suitable for $\mathrm{CO}_{2}$-containing syngas for FischerTropsch synthesis, J. Energy Fuels 23, 4696-4700.

62 Ni X., Tan Y., Han Y., Tsubaki N. (2007) Synthesis of isoalkanes over $\mathrm{Fe}-\mathrm{Zn}-\mathrm{Zr} / \mathrm{HY}$ composite catalyst through carbon dioxide hydrogenation, J. Catal. Commun. 8, 1711-1714.

63 Lee S. Ch., Jang J.H., Lee B.Y., Kim J.S., Kang M., Lee S.B., Choi M.J., Choung S.J. (2004) Promotion of hydrocarbon selectivity in $\mathrm{CO}_{2}$ hydrogenation by $\mathrm{Ru}$ component, J. Mol. Catal. A 210, 131-141.

64 Riedel T., Claeys M., Schulz H., Schaub G., Nam S.S., Jun K.W., Choi M.J., Kishan G., Lee K.W. (1999) Comparative study of Fischer-Tropsch synthesis with $\mathrm{H}_{2} / \mathrm{CO}$ and $\mathrm{H}_{2} / \mathrm{CO}_{2}$ syngas using Fe- and Co-based catalysts, J. Appl. Catal. A 186, 201-213.

65 Zhao G., Zhang Ch., Qin Sh., Xiang H., Li Y. (2008) Effect of interaction between potassium and structural promoters on Fischer-Tropsch performance in iron-based catalysts, J. Mol. Catal. 286, 137-142.

66 Dubois J.L., Sayama K., Arakawa H. (1992) $\mathrm{CO}_{2}$ hydrogenation over carbide catalysts, J. Chem. Lett. 21, 5-8.
67 Toyir J., de la Piscina P.R., Fierro J.L.G., Homs N. (2001) Highly effective conversion of $\mathrm{CO}_{2}$ to methanol over supported and promoted copper-based catalysts: influence of support and promoter, J. Appl. Catal. B 29, 207-215.

68 Siwawut J., Namkhang P., Kongkachuichay P. (2015) Co-metal catalysts on $\mathrm{SiO}_{2}-\mathrm{TiO}_{2}$ for methanol production from $\mathrm{CO}_{2-}$ effect of preparation methods, J. Chem. Eng. Technol. 38, 2153-2160.

69 Kiatphuengporn S., Chareonpanich M., Limtrakul J. (2014) Effect of unimodal and bimodal MCM-41 mesoporous silica supports on activity of $\mathrm{Fe}-\mathrm{Cu}$ catalysts for $\mathrm{CO}_{2}$ hydrogenation, J. Chem. Eng. 240, 527-553.

70 Xiao J., Mao D., Guo X., Yu J. (2015) Effect of $\mathrm{TiO}_{2}, \mathrm{ZrO}_{2}$, and $\mathrm{TiO}_{2}-\mathrm{ZrO}_{2}$ on the performance of $\mathrm{CuO}-\mathrm{ZnO}$ catalyst for $\mathrm{CO}_{2}$ hydrogenation to methanol, J. Appl. Surf. Sci. 338, 146-153.

71 Saito M. (1998) R\&D activities in Japan on methanol synthesis from $\mathrm{CO}_{2}$ and $\mathrm{H}_{2}$, J. Catal. Surv. Jpn. 2, 175.

72 Tremblay J.F. (2008) $\mathrm{CO}_{2}$ as feedstock. Mitsui will make methanol from the greenhouse gas, J. Chem. Eng. News 86, 13.

73 Goehna H., Koenig P. (1994) Producing methanol from $\mathrm{CO}_{2}, J$. Chem. Technol. 6, 36.

74 Shulenberger A.M., Jonsson F.R., Ingolfsson O., Tran K.C. (2007) Process for producing liquid fuel from carbon dioxide and water, US Patent Appl. 0244208A1.

75 Bogdan V.I., Kustov L.M. (2015) Reduction of carbon dioxide with hydrogen on a $\mathrm{Cu}-\mathrm{ZnO}$ mixed catalyst under supercritical conditions, J. Mendeleev. Commun. 25, 446-448.

76 Tursunov O., Kustov L., Tilyabaev Z. (2017) Methanol synthesis from the catalytic hydrogenation of $\mathrm{CO}_{2}$ over $\mathrm{CuO}-$ $\mathrm{ZnO}$ supported on aluminum and silicon oxides, J. Taiwan Inst. Chem. Eng. 78, 416-422.

Manuscript submitted in 10 March 2017 Manuscript accepted in 7 August 2017 Published online in October 2017 